\title{
Features of the Educational Process Subjects Self- Actualization in the Conditions of Mastering the Profession of a Teacher
}

\author{
Bashkireva T.V. \\ Ryazan State University named after S.A. Yesenin \\ Department of General Psychology, \\ S.A. Esenin State University \\ Ryazan, Country Russia \\ bashkirevat@bk.ru
}

\author{
Bashkireva A.V. \\ Department of Biomedical and Psychological Foundations \\ of Physical Education \\ S.A. Esenin State University \\ Ryazan, Country Russia \\ bashkireva32@gmail.com
}

\author{
A. Morozov \\ Research Institute of the Federal Penitentiary Service of Russia \\ SRC-2, "RIFPSR" \\ Moscow, Russia \\ doc_morozov@mail.ru
}

\begin{abstract}
In the conditions of mastering professional activity in the system of higher education, the foundations of a self-actualizing personality of a future specialist are laid. The survey involved students aged 18-20 years, studying in the direction of "teacher education" of various profiles. The scale of the need for security is basic, including the implementation of: biological, mental and social needs. The results of the study showed that young people in the development of professional activities, to fulfill the needs on a safety scale, need to satisfy the need for communication and knowledge. Girls are extremely sensitive to social influences and need approval and creativity. Both boys and girls need self-esteem. In boys, value orientations coincide with social values, and in girls they have a personal character. As subjects of the educational process, young men and women studying at, acquiring psychological and pedagogical knowledge, need support, approval, respect, quality knowledge necessary to meet individual needs and optimal functioning in professional activities.
\end{abstract}

Keywords-self-actualization; subjects of the educational process; personality

\section{INTRODUCTION}

In the process of acquiring professional pedagogical knowledge, from our point of view, a person is more a subject of the educational process. This is due to the fact that the knowledge acquired by students is under the control system of the educational organization. And the degree of satisfaction of needs on the scales of A. Maslow gives us the opportunity to model and adjust the development of self-actualizing personality at the stages of the formation of professional knowledge [14,19].

In philosophical, psychological and sociological Russianlanguage dictionaries, unfortunately, there is no consensus in the wording of the concept of "self-actualization." The Cambridge Dictionary defines the following: "self-actualization - person's desire to use all their abilities to achieve and be everything that they possibly can" [13]. Self-actualization is a multifaceted and complex phenomenon, quite fully described by K. Goldstein and studied in detail by psychologists of the humanistic direction. According to A. Maslow, selfactualization is the desire for self-improvement to realize one's potential, despite the difficulties that accompany a person in ontogenesis, considering it a characteristic of mental health [4; 7]. K. Rogers considered self-actualization as a driving force that makes a person develop from birth to death, including creativity [1]. According to some researchers, the process of self-actualization has two sides: 1) internal, - forming unity, non-integrativity, expressiveness, individuality, versatility and synergy; 2) external - allowing the person to gain positive values (for example: kindness, honesty, courage, love, selflessness, etc.) [10]. These universal values become the property of only a fully developed personality. If the concept of "subject" is chosen, then it becomes necessary to study those group values in which a particular person grew up and was trained [15]. At the same time, turning to professional activity allows us to identify common sociocultural values, especially when it comes to the assimilation of knowledge about professional activity in boys and girls in group interactions [5].

\section{LITERATURE REVIEW}

The difficulty in studying self-actualization lies in the fact that it is a complex integrated education that includes a number of interconnected subjective and personal characteristics [20,21]. Theoretical and empirical studies show that a self-actualizing personality is distinguished by activity, 
1) biological (flexibility of behavior, sensitivity, self-esteem, self-acceptance, autonomy, self-confidence, creativity [3]. Self-actualization acts not only as the highest need and value of the individual, but also manifests itself as a process and property, and its importance on the life path of a person is emphasized [6,17].

Modern social transformations increase the role of a responsible and active attitude of an individual to his development. The study of self-actualization as a mental phenomenon is in demand in the modern socio-cultural situation [9].

However, it should be noted that while in English literature in psychology the dominant concept is personality, then Russian psychology is the subject. We addressed the problem of self-actualization in the subjects of the educational process due to the fact that the correlation of the concepts of "subject" and "personality" in the development of professional activity is not well understood $[11,16]$. Based on the analysis of literary sources, it can be stated that the subject is the bearer of social norms and values, and the personality of social norms and values is formed as a result of deep experiences, based on cognitive dissonance.

The purpose of this research is to study the features of selfactualization in subjects of the educational process in the conditions of professional activity development.

\section{RESEARCH METHODOLOGY}

The methods used in the work: an experiment - studying mental phenomena, the conditions of manifestation and development of which are created artificially, on purpose. In this case, the methods used are: experiment and testing. The data obtained are mathematically processed $(\mathrm{M} \pm \mathrm{m} ; \pm \sigma)$. Statistical analysis and figures are made in Statistca 6.0 software.

We used the methodology of E. Shostrom in the modification of L. Ya. Gozman, M.V. Croz and M.V. Latin [2]. The test for determining the level of personal selfactualization includes 14 scales: orientation in time; need for security; flexibility of behavior; Sensitivity spontaneity; self esteem; self-acceptance; a look at the nature of man; synergy; acceptance of aggression; contact; cognitive needs; creativity. The questionnaire contains 126 points, each of them contains two alternative judgments, one of which is selected and evaluated at one point.

The study involved students $(n=102 ; \hat{\sigma}=44 ;$ 을 $=58)$ aged 18-20 years, studying in the direction of "pedagogical education" of various profiles. Due to the insufficiency of a representative sample, the methodological principle of Occam's razor was used in the analysis of histograms. He argues that if there are several consistent definitions or explanations for a phenomenon, then the simplest of them should be considered true.

\section{RESULTS}

The basis of the analysis was selected the scale of the need for security, which is the base. It includes the most items (91), which indicate the implementation of biological, mental and social needs. We divided this scale into the following blocks: spontaneity, acceptance of aggression, contact), which characterizes such properties of the psyche as: flexibility, sensitivity, poise, aggression, communicativeness

2) mental, characterizing the processes of the psyche (cognitive needs, creativity);

3) social, indicating the role of social values in human development (self-esteem, self-control).

As a result of the analysis, the youth revealed the relationship between the scale of the need for security and such scales as: value orientations $(\rho=0.53 ; \mathrm{P}<0.001)$; flexibility of behavior $(\rho=0.50 ; P<0.01)$; Sensitivity $(\rho=$ 0.57 ; P <0.001); self-esteem $(\rho=0.37$; P <0.05); spontaneity $(\rho=0.42 ; \mathrm{P}<0.01)$; self-acceptance $(\rho=0.41 ; \mathrm{P}<0.01)$; acceptance of aggression $(\rho=0.36 ; \mathrm{P}<0.05)$; contact $(\rho=$ $0.36 ; \mathrm{P}<0.05)$, creativity $(\rho=0.47 ; \mathrm{P}<0.01)$.

In young men in the block of biological needs, adaptation to social conditions on the scales of self-actualization is carried out by contact, which synchronizes such properties of the psyche as: flexibility of behavior, sensitivity, spontaneity, acceptance of aggression. The greatest tension in the development of professional activity is noted on the scales for flexibility of behavior and spontaneity. The higher the level of communication among young men, the higher the need for support and the lower the level of self-actualization. In the development of professional activity, being subjects of the educational environment, they feel the need for communication in order to achieve success in the development of professional activity.

The need for support among girls, as subjects of the educational process, reliably correlates with the following indicators of the scales of self-actualization: orientation in time $(\rho=0.46 ; \mathrm{P}<0.01)$; value orientation $(\rho=0.77 ; \mathrm{P}$ $<0.001)$; flexibility of behavior $(\rho=0.6$; P <0.001); Sensitivity ( $\rho=0.63 ; P<0.001)$; self-esteem $(\rho=0.69 ; P<0.001)$; spontaneity $(\rho=0.67$; $<<0.001)$; self-acceptance $(\rho=0.8 ; P$ $<0.001)$; synergy $(\rho=0.57 ; \mathrm{P}<0.001)$; acceptance of aggression $(\rho=0.64 ; P<0.001)$; contact $(\rho=0.41 ; P<0.05)$; creativity $(\rho=0.6 ; P<0.001)$.

Analysis of the biological unit on the scale of the need for security indicates that the greatest tension in girls is noted on the scale of contact (communication). In girls in the block of biological needs, adaptation to social conditions on the scales of self-actualization is carried out by seasonality, synchronizing such properties of the psyche as: flexibility, poise, aggression; communicative. The higher the sensitivity level of girls, the higher the need for support and the lower the level of self-actualization. In the development of pedagogical activity, they are extremely sensitive to social influences and feel the need for approval.

In the block of mental activity (cognitive needs, creativity) in young people in the development of pedagogical activity, it is important to satisfy the need for knowledge, which generally does not affect self-actualization. Girls have a high need for creativity. The synchronization of management of mental processes is associated with the need for knowledge, the higher the level of knowledge and creativity, the higher the 


\section{References}

level of self-actualization. Our findings confirm the results of studies that intelligence is positively associated with lower needs [12]. For example, creativity measures divergent thinking, creative achievements, actions and shows positive associations with higher levels of human needs [8,18,19,20,21].

The indicators of social influence (value orientations, selfesteem, self-control) on the scale of the need for security for boys and girls in mastering the teaching profession are synchronized with the satisfaction of the need for self-esteem (pic. 3). The higher their level of self-esteem, the lower the need for security, but the higher the level of self-actualization.

In general, both boys and girls, the need for self-esteem has more individual differences $( \pm \sigma=11.9)$. However, in boys, value orientations coincide with social values, while in girls they have a personal character and they socialize faster than boys.

\section{CONCLUSIONS}

At the stages of training in the system of higher education, in the conditions of assimilation of knowledge of psychological and pedagogical knowledge, the foundations of a self-actualizing personality as a future specialist are laid. The scale of the need for security is basic, including the implementation of: biological, mental and social needs.

The results of the study showed the following features of selfactualization of the subjects of the educational process in the conditions of development of pedagogical activity:

1. Boys and girls, in the development of psychological and pedagogical knowledge, feel the need for support, support, communication and knowledge as basic needs for successful professional self-actualization.

2. Girls in the development of psychological and pedagogical knowledge are extremely sensitive to social influences and feel the need for approval and creativity.

3. In boys, value orientations coincide with social values, and in girls they have a personal character. Boys and girls need self-esteem, but this need has individual differences.

Thus, the results of the study showed that boys experience fewer problems in the development of psychological and pedagogical knowledge than girls. The data obtained allow us to argue that in the development of pedagogical professional activity, young men are subjects of the educational process, and girls master the profession personally. As subjects of the educational process, boys and girls need the support, approval, respect, quality knowledge necessary to meet individual needs and optimal functioning in professional activities.
[1] K. Rogers, A Look at Psychotherapy Becoming a Man. M. 1994, pp. 67.

[2] L.Ya. Gozman, M.V. Kroz, M.V. Latinskaya, Self-actualization test. M.: RPA. 1995.

[3] N.F. Kalina, Questionnaire self-actualization of personality. Journal. Practical psychologist. 1998, 1, pp. 65-75.

[4] A.A. Piskoppel, Human nature in the concept of A. Maslow. Questions of psychology. 1999, 2, pp. 75-86.

[5] V.A. Bodrov, Psychology of professional activity. Theoretical and applied problems. Moscow: IP RAS. 2006.

[6] S.L. Bratchenko, M.R. Mironova, Personal growth and its criteria. M. 2007, pp. 45.

[7] A. Maslow, Motivation and personality. SPb. 2001.

[8] N.I. Petrova, The dynamics of self-actualization in students of creative specialties. Questions of psychology. 2003, 1, pp. 45-50.

[9] E.F. Yaschenko, Features of self-actualization of students with different professional orientation. Psychological journal. 2006, 3, pp. 31-41.

[10] C. Beiwen, M. Vansteenkiste, W. Beyers, L. Boone, E. Deci,B. Duriez,W. Lens, L. Matos, A. Mouratidis, R. Ryan, K. Sheldon. S. Soenens, S.Van Petegen. V. Joke. Basic psychological need satisfaction, need frustration, and need strength across four cultures. Motivation and emotion. 2015, 39(2), pp. 216-236. URL: nhttps://biblio.ugent.be/publication/5815011.

[11] T.V. Bashkireva, A.V. Bashkireva, Gender differences in selfactualization among subjects of extreme sports. Human capital. 2016, 10(94), pp. 44-46

[12] Kh. Martskvishvili, N. Sordia, A.C. Neubauer, The Georgian version of the inventory: psychometric properties Educ. Sci. Psychol. 2017, 1(43), pp. 3-17. URL: http://gesj.internetacademy.org.ge/en/list_artic_en.php?b_sec=edu\&issue=2017-03.

[13] Cambridge Business English Dictionary. Cambridge University Press). URL:

https://dictionary.cambridge.org/ru/\%D1\%81\%D0\%BB\%D0\%BE\%D0 $\%$ B2\%D0\%B0\%D1\%80\%D1\%8C1\%D0\%B0\%D0\%BD\%D0\%B3\%D0 \%BB\%D0\%B8\%D0\%B9\%D1\%81\%D0\%BA\%D0\%B8\%D0\%B9/ (06.09.2019).

[14] Compton, C. William, Self-Actualization Myths: What Did Maslow Really Say? Journal of Humanistic Psychology. 2018, pp.1-18. URL: http://journals.sagepub.com/doi/10.1177/0022167818761929.

[15] I.A. Mironenko, The concept of "and" subject "and" personality in modern Russian psychology. Bulletin of the Leningrad State niversity named after S.A. Pushkin. 2010, 3, vol. 5, pp. 5-10. UTL: http://cyberleninka.ru.

[16] I.A. Mironenko, The concept of "and" subject "and" personality "in modern Russian psychology. Bulletin of the Leningrad State University named after S.A. Pushkin, 2010, № 3, vol. 5, pp. 5-10 // http://cyberleninka.ru (06.02.2019).

[17] Saul McLeod, Maslow's Hierarchy of Needs. Simply Psychology, 21 May 2018. URL: https://www.simplypsychology.org/maslow.html.

[18] B. Scott, Kaufman Self-Actualizing People in the 21st Century: Integration with Contemporary Theory and Research on Personality and Well-Being. Article first published online: November 7, 2018. URL: https://journals.sagepub.com/doi/abs/10.1177/0022167818809187.

[19] What is Self-Actualization? A Psychologist's Definition. URL: https://positivepsychologyprogram.com/self-actualization/.

[20] Alexsandr S. Kuznetsov. Russian Professor's meeting. Russian Journal of Physical Education and Sport. 2019, 14(1), pp. 17-22. DOI: 10.14526/2070-4798-2019-14-1-18-24

Understanding Maslow's Theory of Self-Actualization. URL: https://www.thoughtco.com/maslow-theory-self-actualization-4169662 